This is the accepted manuscript version of an article published in the volume Collingwood on Philosophical Methodology, pp 131-149 on January $18^{\text {th }} 2019$. The final publication is available here.

\title{
Collingwood, Pragmatism, and Philosophy of Science
}

\author{
Elena Popa \\ Asian University for Women
}

\begin{abstract}
This paper argues that there are notable similarities between Collingwood's method of investigating absolute presuppositions and contemporary strands of pragmatism, focusing on two areas - the critique of realism and causation. It is first argued that there are methodological similarities between Collingwood's argument against realism and his Kantian-inspired critique of metaphysics, and Putnam's critique of externalism. Regarding causation, it is argued that Collingwood's view and Price's pragmatist approach have a common method - investigating causation in the context of specific human practices. Both authors place causation in the framework of scientific inquiry as opposed to making it the subject of the inquiry itself. Thus, Collingwood's work proves to be in line with current metaphilosophical debates, particularly in the philosophy of science.
\end{abstract}

\section{Introduction: Collingwood's metaphilosophy}

This paper places Collingwood's philosophical methodology in the context of contemporary pragmatist approaches to philosophy of science. I argue that Collingwood's method of investigating absolute presuppositions has important similarities to pragmatist contributions to two important topics in the philosophy of science, namely the debate between realism and anti-realism, and the problem of causation. In this section I discuss Collingwood's method of investigating absolute presuppositions with focus on two uses - his argument against realism, and his analysis of causation. In section 2, I draw a broad connection between Collingwood and pragmatism with emphasis on recent strands of pragmatism that focus on the critique of realism and the primacy of practice. In section 3, I argue that there are significant similarities between Collingwood's critique of realism alongside his broader view on metaphysics and Putnam's critique of externalism. In section 4, I explore the similarities between Collingwood's account of causation and Price's pragmatist approach to causation and critique of causal realism. Section 5 investigates the extent to which Collingwood's work can be classified as pragmatist in the light of the comparisons to Putnam 
and Price. I conclude by placing the affinities between Collingwood's method and pragmatism in a broader perspective, showing how Collingwood's strategy of investigating philosophical problems matches current ways of approaching issues in the philosophy of science. Insofar as these are important approaches to issues such as causation, or realism, Collingwood's work proves to be relevant to these contemporary debates.

Collingwood's views on the issues of realism and causation belong to his broader metaphilosophical approach, especially with respect to metaphysics. In contemporary debates within the philosophy of science, these topics are also subsumed under metaphysics, although the methods of current metaphysics of science are distinct from Collingwood's proposed account. As I will be pointing out, although the discipline is structured differently, there are significant similarities to Collingwood's method when investigating pragmatist approaches to realism and causation.

Regarding methodology, a notable claim from Collingwood's Essay on Philosophical Method (EPM) holds that philosophy 'does not, like exact or empirical science, bring us to know things of which we were simply ignorant, but brings us to know in a different way things which we already knew in some way' (Collingwood 2005: 161). This passage presents the goal of philosophy as uncovering hidden assumptions, and thus bringing previous knowledge into a different light. I take Collingwood's considerations on metaphysics to fall within this broader scope of his philosophy. While it is subject to debate whether Collingwood changed views between EPM and Essay on Metaphysics (EM), I follow interpretations that establish continuity between the two. ${ }^{1}$

Concerning metaphysics, in the beginning of EM, Collingwood rejects the definition of metaphysics as a science of pure being and proposes a view on metaphysics as 'a science of absolute presuppositions' (Collingwood 2002: 41). Collingwood describes propositions as answers to questions; propositions can be propounded, and they can be true or false (23-25). Collingwood further holds that 'every question involves a presupposition' (25). One of the defining features of presuppositions is that they do not need to be true in order to function (28). In distinguishing between relative and absolute presuppositions, Collingwood holds that absolute presuppositions are not propositions, since they do not have a truth value (32). Absolute presuppositions constitute the subject of metaphysics: 'the scientist's business is not to propound them, but only to presuppose them. The metaphysician's business [...] is not to propound them, but to propound the proposition that this or that one of them is presupposed (33). While there are several aspects of interest concerning Collingwood's proposed reform of metaphysics, for my purposes here, the issue of heuristics and modes of inquiry is central. As D'Oro and Connelly state, 'what makes the 
presupposition absolute is that it cannot be forsaken without at the same time undermining the form of enquiry which it makes possible' (2015: 3.2). Martin also emphasizes the role of absolute presuppositions in understanding: 'absolute presuppositions constitute the nature of our understanding within a particular universe of discourse and they govern the inquiry we undertake and the explanations we give there in individual cases' (Martin 2002: xxvi-xxvii). This overall view on Collingwood's method and his considerations on the status of metaphysics enables a closer look at the topics stated above: realism and causation.

Concerning realism, Collingwood's proposed reform of metaphysics, involves the denial of presuppositionless knowledge. As pointed out by D’Oro: 'Collingwood's claim to be practising metaphysics without ontology [...] should be read as putting forward the rather strong claim that there can be no presuppositionless inquiry into reality rather than as stating the rather weaker claim that descriptive metaphysicians should limit themselves to an examination of our ways of thinking and speaking about the world' (2003: 22-23). As a continuation of this project, Collingwood's denial of realism is not what could be labelled as an ontological claim, but rather an epistemological one: "the "realism" which constitutes the target of Collingwood's critique is not the ontological thesis that there exist mind independent objects, but the epistemological thesis that there is such a thing as presuppositionless knowledge of reality (D’Oro and Connelly 2015: 3.2). Collingwood's rejection of realism is explicit in An Autobiography (2013: 44-45):

For if you know that no difference is made to a thing $\theta$ by the presence or absence of a certain condition c, you know what $\theta$ is like with c, and also what $\theta$ is like without c, and on comparing the two find no difference. This involves knowing what $\theta$ is like without $c$; in the present case, knowing what you defined as the unknown.

In relation to presuppositionless knowledge, the argument can be reconstructed as stating that to claim that the world is independent from one's knowledge, one should have access to the world as one knows it, but also to the world independent from one’s knowledge (D’Oro 2003: 42-43). By this, Collingwood rejects realism on the ground that it requires knowledge of things in themselves. The rejection of realism brings forth a comparison to pragmatism. D’Oro, for instance, emphasizes the link to pragmatism with respect to rejecting the correspondence theory of truth. However, despite his criticism of the correspondence theory of truth, unlike pragmatists, Collingwood does not seek to dissolve traditional metaphysical questions, but instead tries to provide a new way of investigating them. Also, unlike pragmatists, Collingwood does not abandon the normative character of philosophy (D’Oro 2003: 47). While D’Oro’s discussion mainly refers to Rorty’s 
version of pragmatism, ${ }^{2}$ in section 4 I will assess Collingwood's stance on the debate between realism and anti-realism, as well as his relation to different strands of pragmatism.

Regarding causation, Collingwood uses his method of investigating absolute presuppositions to identify the presupposition underlying causal thought. ${ }^{3}$ According to Collingwood, this presupposition relies on the ability to distinguish between a present state of affairs which an agent aims to change into an intended state of affairs, 'the causa quod [...] is a situation or state of things believed by the agent in question to exist' and 'the causa ut is a purpose or state of things to be brought about' (Collingwood 2002: 292). This is also reflected in Collingwood's causation in sense I: "that which is "caused" is the free and deliberate act of a conscious and responsible agent, and “causing” him to do it means affording him a motive for doing it' (285). Collingwood deems sense I logically prior to the other two, that is, acting to bring about a certain effect - sense II, or causal interactions between events in nature - sense III (292, 323). This is in line with his earlier claim that absolute presuppositions are logically prior to questions (21), that is, to investigate what caused an event, one presupposes a relation between two events akin to that between an agent and the pursuit of a goal to hold. Notable for the metaphilosophical focus of this paper, investigating causation through the absolute presuppositions underlying causal thought keeps the direction from epistemology to metaphysics: the meaning causation is presupposed to hold connects to the methods of inquiry. I explore this further in section 5.

\section{Collingwood and Pragmatism}

Having sketched Collingwood's considerations on metaphysics, I will now explore the connection to pragmatism. My focus here will rest on more recent versions, as opposed classical pragmatism. This is firstly to emphasize the relevance of Collingwood's work for current developments of pragmatism and philosophy of science. Secondly, since there are several features specific to pragmatist thought, distinguishable in the work of contemporary authors associated with pragmatism, particular characteristics can be broken down for mapping out Collingwood's view. Particularly, I take features within Putnam's and Price's philosophy to match Collingwood's views more closely given the following broad shared characteristics: the denial of the correspondence theory of truth, the denial of distinctions such as appearance-reality or thought-experience, the denial of 'pure being' as the subject of philosophy and the focus on practices of inquiry. I will elaborate on particular issues regarding realism and causation in sections 4 and 5 . For the purposes 
of the current section, I will also point out the links to classic pragmatist thought to provide a cohesive picture of pragmatism and its history, given the difficulty of finding a unifying definition.

In a narrow sense, pragmatism can be defined through the pragmatist maxim, traced to the classic pragmatist philosophers, Peirce, James, and Dewey: 'a distinctive rule or method for becoming reflectively clear about the contents of concepts and hypotheses: we clarify a hypothesis by identifying its practical consequences' (Hookway 2016: 2). This maxim is not universally accepted among later philosophers associated with pragmatism, thus, a definition capturing a broader sense, would associate pragmatism with particular stances on classic philosophical topics and debates. For instance, Putnam singles out the following characteristics of pragmatism: (1) antiscepticism; (2) fallibilism; (3) rejecting the fundamental dichotomy between facts and values; (4) the primacy of practice (Putnam 1994: 152). In Hookway's reconstruction, several other dichotomies are involved beside facts and values, such as mind-body, thought-experience, analyticsynthetic (Hookway 2016: 5). Though Collingwood can be said to share with the classical understanding of pragmatism the focus on method, as well as the aim of conceptual clarification, he does not focus directly on consequences. Rather, a certain concept, or hypothesis is examined in the context of the absolute presuppositions underlying the process of inquiry where the given concepts or hypotheses belong. Note that this does connect to the usage of concepts, and specific epistemic practices, but unlike a view focusing on consequences, Collingwood aims to disclose the absolute presuppositions at work within the given practice.

Earlier pragmatist approaches to truth enabled later views such as Rorty's deflationism, which, as noted by D’Oro (2003), stands in contrast with Collingwood's philosophy. Notably, Rorty adopted a deflationist view on the majority of the traditional problems of philosophy, such as the debate between realism and anti-realism. While Collingwood also criticized truth as correspondence, he did not support anything akin to the pragmatist theory of truth. Thus, given its focus on critiquing traditional philosophical debates and distinctions, Rorty's strand of pragmatism appears to be taking the critique of metaphysics farther than Collingwood. Furthermore, Collingwood proposed the reform of metaphysics through an epistemological project, while Rorty proclaimed 'the death of epistemology'. In the light of these differences, I argue that Collingwood's views are much closer to pragmatist approaches with different focus, such as Putnam's. Firstly, Putnam also rejects the pragmatist theory of truth (and the label of 'pragmatism' altogether). ${ }^{4}$ Secondly, Collingwood's argument against realism fits the project of denying the dichotomy between appearance and reality. As I will argue in the next section, there are important similarities between Collingwood's case against realism, and Putnam's ‘internal realism'. A final common 
point between Collingwood and pragmatist thought for my purposes here is the denial of an a priori metaphysics. I should note a connection with Peirce's considerations on the pragmatist maxim, understood as 'a logical rule that shows the emptiness of "concepts" which have no practical consequences' (Hookway 2016: 6), and thus reveal connections to classical pragmatism. Metaphysics is not concerned with a priori truths about 'pure being' for Collingwood either, but rather with absolute presuppositions, which are investigated in their historical contexts. The claim that certain philosophical problems can be addressed only by investigating human practices (as opposed to a study of 'pure being') is currently adopted by philosophers taking a pragmatist stance, such as Price, Brandom, and Kitcher. In section 5, I will further explore the connection to Price, given the discussion of the common topic of causation.

These broad similarities between Collingwood's work and contemporary contributions to pragmatist thought, particularly by Putnam and Price will provide the framework for a more detailed investigation of pragmatist approaches to the issues of realism and causation. As both issues have been important topics in $20^{\text {th }}$ century philosophy of science, the analysis will stress the importance of Collingwood's work within this field.

\section{Collingwood and Putnam on realism and anti-realism}

In this subsection, I emphasize the similarities between Collingwood's and Putnam's considerations on realism. I focus on the distinction between metaphysical realism and internal realism, as well as on the role of Kant's philosophy as an earlier statement of the views above, and further on a broader metaphilosophical statement concerning the role of metaphysical inquiry. I argue that there are important similarities regarding Collingwood's and Putnam's methods of investigating realism, while the broader aims and philosophical views they endorse are distinct.

Putnam describes metaphysical realism, or externalism, as a view holding that the world is constituted by mind independent objects (Putnam 1981: 49). According to externalism, it is possible to provide a complete description of the world as it is, from a perspective that Putnam deems 'God's Eye point of view'. Putnam contrasts this view with internalism, defined as holding that multiple descriptions of the world are possible from different perspectives 'of actual persons reflecting various interests and purposes that their descriptions and theories subserve', and associates this view with pragmatism (50). According to Putnam, externalism, despite being among the oldest views in philosophy, is untenable; he goes on to defend internalism, whose origins he traces back to Kant.

There are important similarities between Putnam's and Collingwood's views on realism, but there are also points of contrast. Both philosophers rejected the possibility of knowing the world 
from God's Eye viewpoint. The plurality of actual viewpoints sketched by Putnam in terms of interests and purposes can also be explained in terms of absolute presuppositions. According to Collingwood's view, absolute presuppositions underlie scientific theories without being part of the theories themselves, or subject to evaluation with respect to truth value. The further step in bringing these similarities together is to hold that absolute presuppositions express interests and purposes specific to a given historical context of inquiry, which are not questioned among those conducting the inquiry, but subject to philosophical analysis.

Given these similarities, two important divergences should be noted. Firstly, Putnam's description of realism starts off from an ontological perspective, the existence of mind-independent objects, and only later explores its epistemological consequences, i.e., a version of the correspondence theory of truth. As explained above, Collingwood's argument against realism renders attempts to describe the world in terms of mind-independent objects impossible from the onset as such endeavour would assume knowledge of things in themselves. Unlike Putnam's ontological claims, Collingwood's argument against realism relies on an epistemological thesis that it is implossible to know the world in itself. Secondly, while there are epistemological arguments on both sides, it should be noted that sceptical scenarios play an important role in Putnam's defence of internal realism. Namely, Putnam explains that the Brain in a Vat scenario can be readily dismissed by the internalist: in a world where there are brains in vats, one can observe whether other people are brains in vats, but envisioning a world where everyone is a brain in a vat would require God's Eye view (50). This line of defence is not available to the externalist, who would require a justification independent of the individual observer's perspective. As the discussion above shows, this is a refutation of a global sceptical scenario. While scepticism was among the widely discussed topics during Collingwood's time, he did not focus on refuting scepticism (D’Oro 2003: 30). On Collingwood's view, realism does not hold because it rests on an assumption of presuppositionless knowledge, and the ability of answering sceptical arguments is not a decisive point for favouring one view over another.

A different kind of similarity stems from the influence of Kant's philosophy on both thinkers. Putnam identifies Kant as the first representative of internalism, and further explores several Kantian themes in his works (Putnam 1981: 74). While Putnam openly acknowledges Kant's view as crucially important to his approach, the connection between Collingwood and Kantian philosophy is subject to debate (D’Oro and Connelly 2015: 5.3). For my purposes here I rely on certain important Kantian themes in Collingwood's work identified D’Oro: both philosophers' proposals for reforming metaphysics, their acknowledgement of a distinction between ontological and epistemological dimensions of idealism, and philosophical method - namely 
explaining our experience in EM, or its conditions of possibility in Kant's Critique of Pure Reason (D’Oro 2003: 25-28). These similarities show important convergences between the views of the two philosophers.

Comparing how Kant's philosophy influenced Collingwood and Putnam, the most important themes to stress are realism and the reform of metaphysics. I take the following claim by Putnam to be relevant: "if we do shift our way of thinking to the extent of regarding "the world" as partly constituted by the representing mind, then many things in our popular philosophy (...) must be reexamined. (...) Kant held that (...) this philosophical question was never going to be solved by empirical science. I am suggesting that on this subject Kant was right' (Putnam 1992: 162). This passage showing Putnam's opposition to realism, is remarkably similar to Collingwood's argument: the world being partly constituted by the mind entails that there is no mind-independent, i.e., presuppositionless knowledge. Furthermore, convergence on the wider metaphilosophical stances of the two philosophers and Kant is revealed: the debate between realism and anti-realism cannot be solved by the means of science, and belongs to the realm of metaphysics. This falls in line with Collingwood's claim that absolute presuppositions fall within the area of metaphysical investigation, and are different from empirical claims, for instance, by not having a truth value.

The considerations above provide an insight into the pragmatist topics within Collingwood's and Putnam's work. Directing the investigation towards philosophy of science, there is a question concerning realism as a matter of degree. While both Collingwood and Putnam deny a particular strand of realism that has dominated philosophy for centuries, so far I did not clarify the extent to which they reject realist assumptions. To answer this question, I rely on the view that commitments to realism come in degree, as contemporary discussions on objectivity and scientific realism have shown. ${ }^{5}$ Putnam criticized externalism and the correspondence theory of truth, while at the same time supporting a different branch of realism, concerning theoretical entities (such as electrons). One of his well-known statements is that: 'realism is the only philosophy that doesn't make the success of the science a miracle' (Putnam, 1975: 73). While Putnam is a critic of realism, he does not entirely dispense with realist tenets, particularly regarding theoretical entities in the sciences. Thus, if we view the philosophical stances between realism and anti-realism as a spectrum, Putnam's overall view would be closer to realism than Collingwood's. As Collingwood was not particularly concerned with theoretical entities, it would be difficult to reconstruct his stance on this issue for comparison with Putnam's view. A preliminary conclusion of the discussion above is that Collingwood and Putnam use comparable strategies in attacking realism, and trace 
their stance regarding metaphysics to similar historical sources. Nevertheless, their ultimate conclusions are different.

To sum up, Collingwood's work has similarities to Putnam's stance on pragmatism, namely involvement in the debates over realism and anti-realism and particularly the critique of realism. While their contributions reflect rejections of particular dichotomies, notably between primary and secondary qualities, and appearance and reality, neither philosopher pursued dissolving philosophical problems as other strands of pragmatism proposed. Broadly, this fits the project of reforming metaphysics, or, more narrowly, the metaphysical debates over realism, and both philosophers converge on the view that the investigation of these issues is not empirical. While there are differences in their engagement with ontology, the problem of skepticism, and to what degree the two philosophers are realist, there are methodological similarities and shared historical influences. I take these similarities to be important especially given the metaphilosophical dimension of Collingwood's work and of pragmatism: the strategy he employed is largely compatible with Putnam's pragmatist approach. However, in the next section I show how Collingwood's treatment of causation brings his view closer to Price's pragmatism than to Putnam's.

\section{Collingwood and Price on investigating causal concepts through human practices}

In the context of Collingwood's philosophy, the analysis of causation is an illustration of his method of investigating absolute presuppositions. The connection between causation and realism, examined in the previous section, should also be noted: Price, whose views I compare to Collingwood's, favours a projectivist view over realism: causation is said to be a secondary quality, tied to specific human capacities. ${ }^{6}$ Price (2001) presents this view in a pragmatist key and also points to a connection with Putnam's denial of the distinction between primary and secondary qualities, which is part of Putnam's broader critique of externalism described above. The difference to stress, however, is that Collingwood's discussion of the three senses of causation targets three types of causal explanation, and thus there is no ontological commitment regarding causation. As I will explain below, while Price discusses a version of ontological subjectivity, which would run against causal realism, he focuses on a practice-driven sense. Thus, insofar as neither Collingwood, nor Price, commit themselves to realism, the similarity between their overall views appears to be stronger than in Putnam's case. In this section, I explore specific similarities regarding causation. 
Price draws several distinctions with respect to subjectivity about causation, one of which refers to ontology, but focuses on one aspect: the practice-subjectivity of causation. He acknowledges this as a pragmatist stance: 'the practice-subjective doctrine that we don't understand the notion of causation — as philosophers, as it were - until we understand its origins in the lives and practice of agents such as ourselves' (Price 2001: 107). He traces this strategy of analysing causation to Ramsey's (1978) considerations on probability, which, in Price's interpretation, cannot be characterized without its role in decision-making, which is a human endeavour (Price 2001: 107). Price distinguishes between global pragmatism and pragmatism about causation on the basis of a divergence between the realist doctrine about theoretical entities and causal realism. Briefly, his view goes as follows: 'being realist about causation is not like being realist about electrons, or any of the other postulates of the special sciences. Causation is different, and it is pragmatism, not realism, which offers an account of the difference' (120). How does pragmatism explain the difference? According to Price, the role of causation in the sciences is different from that of theoretical entities: 'causation is the medium in which the investigation is conducted, the thread which leads to unseen objects. Treat the thread itself as unknown, and we are simply blind' (114). Since the details of Price's argument go beyond the purpose of my paper, I will comment on his overarching view. ${ }^{7}$

There are several analogies to draw between Price's project and Collingwood's approach. Firstly, the subjective component of causation under Price's view, namely the agent's situation, is consistent with Collingwood's formulation of the absolute presupposition underlying causal thought, i.e., a reason prompting a particular action. The more general presupposition rests on an explanation scheme involving causa quod (efficient cause) and causa ut (final cause) which are present in Collingwood's explanation of sense I causation - performing an action in pursuit of a goal. As specified in section 1, according to Collingwood, this sense is prior to the other two senses - the causal connection between an action and its effect (sense II), or between events in nature (sense III). Thus, on Collingwood's view, notably, causal explanation in history is rendered possible by the presupposition that agents perceive the distinction between a current and a desired state of affairs and act to bring about the latter. ${ }^{8}$ While causal explanation in history is central to Collingwood's work, the model can be extended to a broader claim that absolute presuppositions render specific forms of inquiry possible (as illustrated by causal explanations reliant on senses II and III). These tenets by Collingwood can be represented as standing in logical connection with 
Price's claim that causation is only understood by investigating the agent's practices, particularly decision-making. To clarify how Price’s claim can be a consequence of Collingwood's global view:

1. Absolute presuppositions enable means of inquiry specific to particular sciences (Collingwood's definition of absolute presuppositions).

2. Absolute presuppositions are the object of study of philosophy (Collingwood's EM, EPM).

3. The absolute presupposition enabling causal thought consists of a distinction between a current and a desired state of affairs and the ability to act to enact the latter - the relation between causa quod and causa ut (Collingwood on causation).

4. The ability to act such as to turn a current state of affairs into a desired one (the relation between causa quod and causa ut) is characteristic of human agents and tied to human practices.

5. Therefore, a philosophical analysis of causal concepts in the context of scientific inquiry can only be conducted by investigating human agents' practices (Price's pragmatism about causation).

If this is correct, Price's view may be logically connected to an overall view on the presuppositions underlying causal thought of the kind Collingwood supports. To put it another way, questions concerning causation are enabled by a stance that takes into consideration an agent's actions and perspective. As specified above, while Collingwood's analysis connecting motives to actions mainly applies to history, causal thought is modelled on human practices in the case of other special sciences too, as Price's considerations on decision-making show. Further in-depth similarities between Collingwood's view and Price's perspectivalism are explored elsewhere. ${ }^{9}$ While this point shows Collingwood's work to be relevant to contemporary debates on causation and agency, the connection to pragmatism will be more thoroughly established in what follows.

The other important point to make in this section is that the distinction between first order entities in science and causation as a medium for the investigation made by Price in a pragmatist context can also be drawn using Collingwood's method. The project of investigating absolute presuppositions rests on a distinction between scientific knowledge and the presuppositions enabling the inquiry. On this view, causal connections are not akin to the entities scientists posit, but, rather, belong to the category of absolute presuppositions rendering the whole process of inquiry possible. To investigate the causal powers of electrons is to assume that looking for properties which enable an entity to cause certain events is a valid way of conducting research. For comparison, I refer to Collingwood's example concerning the absolute presupposition that events are caused: 
[I]f you were talking to a pathologist about a certain disease and asked him 'What is the cause of event $\mathrm{E}$ which you say sometimes happens in this disease?' he will reply 'The cause of E is C'; and if he were in a communicative mood he might go on to say 'That was established by So-and-so, in a piece of research that is now regarded as classical.' You might go on to ask 'I suppose before So-and-so found out what the cause of $\mathrm{E}$ was, he was quite sure it had a cause?'. The answer would be 'Quite sure, of course.' If you now ask 'Why?' he will probably reply 'Because everything that happens has a cause.' If you are importunate enough to ask 'But how do you know that everything that happens has a cause?' he will probably blow up right in your face, because you have put your finger on one of his absolute presuppositions, and people are apt to be ticklish in their absolute presuppositions. But if he keeps his temper and gives you a civil and candid answer it will be to the following effect. 'That is a thing we take for granted in my job. We don't question it. We don't try to verify it. It isn't a thing anybody has discovered, like microbes or the circulation of the blood. It is a thing we just take for granted' (Collingwood 2002: 31).

As this passage shows, the role of causation is not to be sought among the first order entities used in research on pathology. Rather, causation is part of the absolute presuppositions enabling the inquiry. This point is in line with Price's pragmatism regarding stipulating a different status for causation in comparison to first order entities in the sciences. While no claims about what microbes bring about what disease can be made without a concept of causation, causation itself cannot be investigated by the methods of pathology. Moreover, Collingwood also mentions that this presupposition no longer holds in every area of science, which is also in line with Price's considerations on causation in the special sciences, and with further contemporary debates on whether there is causation in fundamental physics. ${ }^{10}$ It should be noted that this investigation can be extended to Price's overall pragmatist view involving 'practical stances', causation being one instance among examples such as probabilities and conditionals (Price 2013: 47-48). Insofar as absolute presuppositions underlie various forms of inquiry, causal thought alongside other means of investigation enable various scientific fields without being part of the content of the said sciences. ${ }^{11}$ metaphysics and Carnap's considerations on the internal/external distinction. Carnap criticizes metaphysics for aiming at answering external questions while questions in general can only be answered within a frame. Collingwood's view supports this distinction, but shifts the object of metaphysics to the frame itself (D’Oro 2015). 
In the light of the point above, the affinity between Collingwood's view on causal explanation and Price's pragmatism can be further emphasized. Both authors distinguish between first order claims of specific sciences and the frame of inquiry, and on both views causal concepts can be fully analysed only by reference to the human practices constituting the frame. Thus, when causal concepts are used in explanations in the special sciences, they inevitably reflect aspects of the human subject. This point is emphasized by Price when discussing Putnam's interpretation of Kant and instrumentalism - causal explanations are significant from the perspective of human concerns rather than by reference to a mind-independent reality. Thus, Collingwood and Price converge on a view on causation as fundamentally connected to human practices and causal explanation is always set against a corresponding frame of inquiry. Price (2001: 108) holds that if there were no thinking beings there would be no causal concepts, and, by extension, no search for causal explanations.

In summary, there are notable affinities between Collingwood's method of investigating absolute presuppositions together with his specific view on causation and Price's pragmatism. Firstly, understanding causation through an absolute presupposition that refers to a human capacity (acting in pursuit of goals) entails a view on causal understanding along the lines of Price's practice-subjectivity - i.e., we can understand causation only by looking into its origins in particular human practices. Secondly, the role of causation in scientific inquiry is similar within Collingwood's method of investigating absolute presuppositions and Price's pragmatist framework: causation is not part of the set of entities scientists postulate, but part of the broader frame of inquiry, which enables research in a given field. The resulting causal explanations are dependent on the corresponding frame on both views.

\section{Collingwood's pragmatism}

Having mapped out different strands of pragmatism and highlighted similarities between Collingwood's thought and contributions to pragmatism by Putnam and Price, I will end by placing Collingwood's view among the aspects of pragmatism discussed so far. This will enable an assessment of the extent to which Collingwood's philosophy can be classified as pragmatist. In the light of the discussion above, this section holds that Collingwood's view is closer to Price's with regard to the considerations on a frame of inquiry and causal explanation. At the same time, there are notable affinities between Collingwood's views and Putnam's contributions to pragmatism with regard to ways of contesting metaphysical realism and traditional philosophical dichotomies which are also present in Price’s pragmatism. 
Broadly, Collingwood's critique of realism and the correspondence theory of truth is consistent with the multiple strands of pragmatism explored here. Nevertheless, the proposed reform of metaphysics sets Collingwood apart from a pragmatist theory of truth and the denial of traditional philosophical debates as in Rorty's pragmatism, while his reliance on epistemology as opposed to ontology excludes views such as Putnam's internal realism. In terms of placing Collingwood's view on a spectrum between realism and anti-realism, in the light of the present analysis, Price's pragmatism about causation appears to be the closest. The analysis of causal concepts in the context of human practices parallels Collingwood's statement of the absolute presupposition underlying causal thought, and placing causation within the frame as opposed to the content of inquiry. A further common point emerges when considering the connection between the frame of inquiry and causal explanations: causal explanations and uses of causal concepts generally are dependent on the frame as opposed to referring exclusively to mind-independent entities. In Collingwood's case this frame is constituted by absolute presuppositions, while Price distinguishes between the investigation itself and its medium with causation belonging to the latter. Nevertheless, the views converge as far as pragmatism about causal concepts and the rejection of realism is concerned. A question arising here is whether Collingwood's considerations on absolute presuppositions may be closer to a kind of global pragmatism as opposed to Price's pragmatism about causation. Noting that an answer to this question would require further investigation of certain claims belonging to scientific realism that Price refers to, such as entity realism, I restrict my comparison to a broad feature of pragmatism - the reference to human practices - and the resulting view on philosophical concepts such as causation. As causation was one particular illustration of Collingwood's method of investigating absolute presuppositions, pragmatist analyses of further concepts are possible, without necessarily committing to global pragmatism.

Having noted the pragmatist treatment of causation in the case of both Price and Collingwood, alongside the critique of realism, one final point to note is that much of Price's discussion relies on Putnam's contributions to pragmatism, particularly concerning the denial of philosophical dichotomies and contributions regarding instrumentalism. Thus, despite the divergences concerning realism and ontology, the methodological similarities between Collingwood's investigation of absolute presuppositions and Putnam's and Price's pragmatism should be emphasized. The denial of 'God's eye' perspective on metaphysics, and presuppositionless knowledge enabled similar critical stances towards dichotomies such as appearance and reality, or primary and secondary qualities, and thus a pragmatist outlook on philosophy. 
Thus, the connections between Collingwood's views and the strands of pragmatism discussed here are twofold. Firstly, in terms of distinguishing between a frame of inquiry and first order scientific knowledge and articulating a pragmatist view on causal concepts with the potential of providing similar analyses to other concepts, Collingwood's view is closer to Price’s. Secondly, a focus on methodology reveals similarities to Putnam's critique of metaphysical realism, and a pragmatist viewpoint on important philosophical debates, with the notable exceptions of scepticism and ontological inquiry. This shows a complex picture of affinities along different aspects of Collingwood's work and different strands of pragmatism.

\section{Conclusion: Collingwood and pragmatist approaches to realism and causation}

This paper has explored similarities between Collingwood's overall method of investigating presuppositions applied to the issues of realism and causation, and current strands of pragmatism by Putnam and Price. Analysing Collingwood's critique of realism in comparison to Putnam's, I noted that both philosophers denied certain traditional philosophical dichotomies (thought vs. experience, primary vs. secondary qualities, appearance vs. reality etc.), while being participants in debates concerning others (realism vs. anti-realism). From a methodological point of view, both philosophers took the problem of realism to be the subject of philosophy, as opposed to empirical science. This points to deep methodological similarities between the two thinkers, and emphasizes the compatibility between Collingwood's approach and the pragmatist strategy. This point is further strengthened by the divergences between Putnam and Collingwood concerning arguments against realism and Putnam's focus on scepticism, and the ultimately different conclusions regarding realism - Putnam's critique is meant to support a different kind of realism, while Collingwood's critique is meant to establish that the claim that the world is independent of the subject's knowledge cannot hold, given the impossibility of presuppositionless knowledge. While the two philosophers pursued different aims, the methods they employed led them to views marked by some of the main tenets of pragmatism.

The investigation of Price's pragmatist stance on causation and Collingwood's considerations on the absolute presupposition underlying causal thought has shown similarities regarding both methodology, as well as concerning the view on the role of causation in scientific inquiry. On both authors' accounts, causation is to be investigated in the context of specific human practices from which causal thought arises, particularly in connection to agency. Likewise, on both views there is a distinction between the main tenets of science and the tenets and concepts that shape the process of inquiry, and causation is part of the latter. I take this final point to be the main 
point of convergence between Collingwood and the pragmatist views explored here: current debates in the philosophy of science have involved distinctions between first order entities and a certain frame, or set of conditions for the inquiry. As pointed out above, a similar strategy was employed by Collingwood in his suggestion of reforming metaphysics. The subsequent debates within the philosophy of science, especially those pertaining to pragmatism, emphasize the importance of drawing the distinction in the first place, and the need for further research on methodology: how do specific methods and practices affect our understanding of concepts used in the sciences? In this respect Collingwood's work on causation deserves further emphasis, both through its focus on action, which is gaining wide acceptability in current debates, as well as through the epistemically driven method: one can find out what causation is by studying one's means of investigating causal connections.

From the broader perspective of contemporary debates on metaphilosophy, the current paper has shown that Collingwood's method is comparable to particular pragmatist approaches: Putnam's critique of metaphysics, and Price's considerations on causation, a frame of inquiry, and human concerns. While Collingwood does not subscribe to a fully deflationist view, his proposed reform of metaphysics does away with certain traditional distinctions and assumptions. In the light of the argument here, Collingwood's view can be said to have anticipated metaphysical debates concerning scientific concepts and practices of inquiry, and to have provided a method that can be used in addressing some of these issues.

\section{Acknowledgements}

I am grateful to Giuseppina D’Oro and Karim Dharamsi for comments that helped strengthen this paper, and to Stephen Leach for editorial suggestions.

\section{References}

Boucher, David, and Teresa Smith, eds. RG Collingwood: An Autobiography and other writings: with essays on Collingwood's life and work. OUP Oxford, 2013.

Chakravartty, Anjan, "Scientific Realism”, The Stanford Encyclopedia of Philosophy (Summer

2017 Edition), ed. Edward N. Zalta, URL =

$<$ https://plato.stanford.edu/archives/sum2017/entries/scientific-realism/>.

Collingwood, Robin George. "On the so-called idea of causation." In Proceedings of the Aristotelian society, vol. 38, pp. 85-112. Aristotelian Society, Wiley, 1937. 
Collingwood, Robin George. The idea of history. Oxford University Press on Demand, 1994.

Collingwood, Robin George. An essay on metaphysics. Oxford University Press, 2002.

Collingwood, Robin George. An essay on philosophical method. Clarendon Press, 2005.

Dharamsi, Karim, D’Oro, Giuseppina, and Leach, Stephen, “Editorial Introduction” in Collingwood on Philosophical Methodology, ed. Karim Dharamsi, Giuseppina D’Oro, and Stephen Leach, Palgrave, forthcoming.

D’Oro, Giuseppina and Connelly, James “Robin George Collingwood”, The Stanford Encyclopedia of Philosophy (Summer 2015 Edition), ed. Edward N. Zalta, URL = $<$ http://plato.stanford.edu/archives/sum2015/entries/collingwood/>.

D’Oro, Giuseppina. “Unlikely Bedfellows? Collingwood, Carnap and the Internal/External Distinction.” British Journal for the History of Philosophy 23, no. 4 (2015): 802-817.

D’Oro, Giuseppina. Collingwood and the Metaphysics of Experience. Routledge, 2003.

Douglas, Heather. "The irreducible complexity of objectivity." Synthese 138, no. 3 (2004): 453-473. Field, Hartry. "Causation in a physical world." Oxford handbook of metaphysics, ed. Michael J. Loux and Dean W. Zimmerman (2003): 435-460.

Hookway, Christopher, "Pragmatism”, The Stanford Encyclopedia of Philosophy (Summer 2016 Edition), ed. Edward N. Zalta, URL $<$ https://plato.stanford.edu/archives/sum2016/entries/pragmatism/>.

Kant, Immanuel. Critique of pure reason. Cambridge University Press, 1998.

Martin, R. “Editor’s Introduction”, in Robin George Collingwood. An essay on metaphysics. Oxford University Press, 2002.

Menzies, Peter, and Huw Price. "Causation as a secondary quality." The British Journal for the Philosophy of Science 44, no. 2 (1993): 187-203.

Popa, Elena. "Collingwood and Manipulability-based Approaches to Causation: Methodological Issues.” Collingwood and British Idealism Studies 22, no. 1 (2016): 139-166.

Price, Huw "Causation in the special sciences the case for pragmatism." in Domenico Costantini, Maria Carla Galavotti and Patrick Suppes, eds. Stochastic Causality, CSLI Publications, 2001, 103 $-120$.

Price, Huw. “Agency and probabilistic causality.” The British Journal for the Philosophy of Science 42, no. 2 (1991): 157-176.

Price, Huw. "Causal Perspectivalism.” in Huw Price and Richard Corry (eds.). Causation, Physics, and the Constitution of Reality: Russell's Republic Revisited, Oxford University Press, 2007, 250292. 
Price, Huw. Expressivism, Pragmatism, and Representationalism, Cambridge: Cambridge University Press, 2013.

Putnam, Hilary. Philosophical Papers: Volume 1, Mathematics, Matter and Method. Vol. 1. Cambridge University Press, 1979.

Putnam, Hilary. Realism with a human face. Harvard University Press, 1992.

Putnam, Hilary. Reason, truth and history. Vol. 3. Cambridge University Press, 1981.

Putnam, Hilary. Words and life. Harvard University Press, 1995.

Ramsey, Frank Plumpton. “General Propositions and Causality”. In Foundations: Essays in Philosophy, Logic, Mathematics and Economics. ed. D.H. Mellor. London: Routledge \& Kegan Paul, 1978, 133-151.

Rorty, Richard, Hilary Putnam, James Conant, and Gretchen Helfrich. "What is pragmatism?.” Think 3, no. 8 (2004): 71-88.

Rorty, Richard. Consequences of pragmatism: Essays, 1972-1980. U of Minnesota Press, 1982.

Rorty, Richard. Objectivity, relativism, and truth: philosophical papers. Vol. 1. Cambridge University Press, 1991. 